\title{
Review
}

Ophthalmologica

\section{Predicting Visual Outcome following Surgery for Idiopathic Macular Holes}

\author{
Sentaro Kusuhara Akira Negi \\ Division of Ophthalmology, Department of Surgery, Kobe University Graduate School of Medicine, Kobe, Japan
}

\section{Key Words}

Macular hole $\cdot$ Vitrectomy $\cdot$ Predictor $\cdot$ Visual acuity

\begin{abstract}
Since Kelly and Wendel [Arch Ophthalmol 1991;109:654659] first reported successfully treating macular holes (MHs) using pars plana vitrectomy in 1991, MH surgery has been constantly improved. For example, introducing the removal of the internal limiting membrane considerably increased the closure rate of $\mathrm{MHs}$, and the advent of microincision vitrectomy surgery reduced surgical trauma and decreased patient discomfort after surgery. As modern MH surgery can achieve a higher anatomical success rate and alleviate patients' postoperative distress, postoperative visual outcomes have lately become the primary concern. Informing patients of the expected visual acuity and visual improvement before surgery is ideal, but predicting postoperative visual outcomes is difficult because a large number of factors are associated with them. In this paper, we review previous studies and provide accumulating evidence for the relationship between individual prognostic factors and visual outcomes after MH surgery.

(c) 2013 S. Karger AG, Basel
\end{abstract}

\section{Introduction}

Idiopathic macular hole $(\mathrm{MH})$ is one of the major vitreoretinal disorders that cause metamorphopsia and poor central vision in the elderly. MHs are more common in women $[1,2]$, and the estimated incidence is reported to be 7.8 new cases per 100,000 population per year [3]. Since Kelly and Wendel first reported the successful closure of idiopathic $\mathrm{MH}$ with pars plana vitrectomy and fluid-gas exchange in 1991 [4], several modifications have been made to improve surgical outcomes. The introduction of internal limiting membrane (ILM) peeling to $\mathrm{MH}$ surgery improved the closure rate dramatically $[5,6]$. Triamcinolone acetonide is now almost routinely used to visualize the vitreous body, contributing to better removal of the residual posterior vitreous cortex and a decrease in postoperative ocular inflammation [7]. Microincision vitrectomy surgery has decreased the operating time, reduced postoperative inflammation and astigmatism formation, and improved patient comfort [8]. Furthermore, multiple lines of evidence have revealed that postoperative face-down positioning can be shortened or is even unnecessary in patients with a small $\mathrm{MH}$, which considerably alleviates patient suffering $[9,10]$. With the improved closure rate and decreased surgery-related risks and distress, the degree of postoperative visual recovery

\section{KARGER}

E-Mail karger@karger.com www.karger.com/oph
(C) 2013 S. Karger AG, Basel

0030-3755/13/2313-0125\$38.00/0
Sentaro Kusuhara, MD, $\mathrm{PhD}$

Division of Ophthalmology, Department of Surgery Kobe University Graduate School of Medicine

7-5-2 Kusunoki-cho, Chuo-ku, Kobe 650-0017 (Japan)

E-Mail kusu@med.kobe-u.ac.jp 
has become a chief concern for modern MH surgery. As ophthalmologists are responsible for informing patients of their expected visual recovery before surgery, we have reviewed the preoperative predictive factors for visual outcome following idiopathic MH surgery in this paper.

\section{MH Surgery}

Because vitreous surgery for idiopathic $\mathrm{MH}$ is composed of several distinct steps, there are many technical variants that seem to be important in discussing preoperative predictive factors. Accordingly, we first briefly review the possible effects of each variant on the visual outcome.

\section{Intraocular Tamponade Agents and Postoperative}

Face-Down Posturing

There has been controversy concerning the selection of the intraocular tamponade agent and the optimum duration of face-down posturing following $\mathrm{MH}$ surgery [911]. Two comparative studies in the 1990s showed that the use of long-acting $\mathrm{C}_{3} \mathrm{~F}_{8}$ gas and prolonged prone positioning (for more than 2 weeks) provided a better improvement in visual acuity and a higher rate of $\mathrm{MH}$ closure $[12,13]$. However, later trials found that a short tamponade by short-acting gases and shorter face-down posturing (for up to 10 days) provided anatomical and visual outcomes comparable to those associated with a longer tamponade [5, 14-16]. Moreover, two recent multicentre randomised controlled trials (RCTs) suggested that no face-down posturing was necessary for small $\mathrm{MHs}$ $(<400 \mu \mathrm{m})[15,16]$.

\section{ILM Peeling and Adjuvant}

ILM removal during $\mathrm{MH}$ surgery is widely accepted to significantly improve the likelihood of hole closure $[6,17$, 18]. Although the benefit of ILM peeling on the visual outcome had long been unclear, one recent RCT concluded that there was no difference in distant visual acuity at 6 postoperative months between the ILM-peel and noILM-peel groups [19]. Nevertheless, ILM peeling is still thought to be important, especially in eyes with large $\mathrm{MHs}$, because ILM removal facilitates the anatomic closure of large MHs, although it is not always associated with good visual recovery [18]. Recently, in a prospective randomised study of 102 eyes with large $\mathrm{MHs}(>400 \mu \mathrm{m})$, Michalewska et al. [20] reported the inverted ILM flap technique, which improved both the functional and anatomical outcomes compared with standard ILM removal.
Because peeling of the colourless thin ILM is a challenging manoeuvre even for experienced vitreoretinal surgeons, several adjuvants are intraoperatively used to facilitate ILM removal. Indocyanine green (ICG) is a fluorescent dye that formerly gained widespread use to visualise the ILM. However, there were concerns regarding the safety of ICG use [21], and recent meta-analyses of ILM peeling in $\mathrm{MH}$ surgery showed that visual outcomes were significantly worse in the group with ICG application [22, 23]. Trypan blue and triamcinolone acetonide have been used to replace ICG [24-27], but there are reports suggesting retinal toxic effects associated with these agents [2830]. The recently introduced brilliant blue $\mathrm{G}$ (BBG) is thought to be a promising dye. In a rat model of subretinal injection, BBG did not cause any detectable toxic effects on retinal cells, whereas ICG and trypan blue caused retinal degeneration [31]. Moreover, the BBG dye acts as a P2RX7 antagonist and can mediate neuroprotective effects on retinal neurons $[32,33]$. As the favourable effects of BBG dye use in $\mathrm{MH}$ surgery on visual outcomes have been confirmed in several comparative studies [34, 35], the benefits of BBG use should be evaluated in an RCT.

\section{Microincision Vitrectomy Surgery}

Since Fujii et al. [36] first successfully performed a sutureless transconjunctival vitrectomy using commercially available 25-gauge instruments, microincision vitrectomy surgery gained popularity throughout the past decade because of the advantages over the conventional 20 -gauge approach, including shorter surgery time, increased patient comfort and rapid vision recovery [8]. There have been several studies focusing on the effects of gauge selection on visual outcomes following $\mathrm{MH}$ surgery. In a comparative study of $47 \mathrm{MH}$ cases, 25-gauge vitrectomy yielded similar visual outcomes, visual acuity and visual improvement at 6 postoperative months to those of 23-gauge vitrectomy [37]. In another comparative study of $72 \mathrm{MH}$ cases, the 23-gauge vitrectomy group had a visual acuity improvement similar to the improvement in the 20-gauge vitrectomy group [38]. In a prospective study of $23 \mathrm{MH}$ cases, the difference in the final visual acuity was not significant between 23 - and 20-gauge vitrectomy [39]. A case series reported that 27-gauge $\mathrm{MH}$ surgery was feasible, although the advantage in visual outcomes compared with the other microincision vitrectomy surgeries remains elusive [40].

\section{Others}

In a case series of $29 \mathrm{MH}$ eyes, triamcinolone acetonide use for the visualisation of the posterior hyaloid during 
MH surgery did not have a significant effect on the average improvement of visual acuity [41]. A cohort study of 74 eyes demonstrated that the surgical time did not increase the risk of the progression of nuclear sclerosis following $\mathrm{MH}$ surgery, although vitrectomy itself was highly associated with cataract progression [42]. The temporal visual field defect is a severe complication of $\mathrm{MH}$ surgery that may be caused by mechanical or dehydration injury from air streaming during the fluid-air exchange. Several case series have demonstrated that this visual field defect can be reduced using humidified air or a low air pressure $[43,44]$.

\section{Preoperative Predictive Factors}

There is a large volume of literature regarding the predictors of the visual results following $\mathrm{MH}$ surgery. We focus on preoperative predictive factors in this review.

\section{Stage of $M H$}

The stage of $\mathrm{MH}$ is an important prognostic factor for postoperative visual acuity [6]. In a meta-analysis, a postoperative visual acuity of $6 / 12$ or better was achieved in $65.9 \%$ of the stage $2 \mathrm{MH}$ group. This figure is significantly higher than in the stage 3 and $4 \mathrm{MH}$ group (15.0\%) [45]. A multiple regression analysis using the RCT data of the Moorfields Macular Hole Study also concluded that the advanced stages had a worse visual outcome [46].

\section{Duration of Symptoms}

Eyes with a shorter duration of symptoms have been well recognised to have a better visual outcome after $\mathrm{MH}$ surgery. In a series of 58 eyes treated with pars plana vitrectomy with ILM removal and air tamponade, a final visual acuity of $20 / 50$ or better was achieved in $60 \%$ of cases with a duration of less than 6 months and in $31 \%$ of cases with a duration of 6 months or longer [5]. Several lines of evidence have shown that the chance of recovering good visual acuity following $\mathrm{MH}$ surgery is decreased if the duration of symptoms is longer than 12 months [47-50]. In a series including 55 cases, the percentage of eyes reaching a postoperative visual acuity of $6 / 12$ or better was $52 \%$ in the cases with a duration of 6 months or shorter, $67 \%$ in the cases with a duration of 6-12 months, and $16 \%$ in the cases with a duration of longer than 12 months [50]. In a retrospective review of 24 chronic $\mathrm{MH}$ eyes with a duration of $1-3$ years, $25 \%$ of the eyes had a visual acuity of $6 / 12$ or better at 6 postoperative months [48]. In another case series of 23 chronic $\mathrm{MH}$ eyes with a duration of more than 1 year, only $8.7 \%$ of the treated eyes

Predicting Visual Outcome after $\mathrm{MH}$ Surgery achieved a visual acuity of better than 20/40 [49]. In a meta-analysis investigating the effects of the duration of symptoms on the surgical outcomes, there was no significant difference in the visual outcomes in the cases with stage $2 \mathrm{MHs}$. In contrast, the duration of symptoms was a significant determinant of postoperative visual acuity in the cases with stage 3 or $4 \mathrm{MHs}$. Although the average duration of symptoms for the eyes that succeeded in attaining a postoperative visual acuity of $6 / 12$ or better was 3.2 months, the average duration of symptoms for the eyes that failed was 7.4 months [45].

\section{Preoperative Visual Acuity}

Preoperative visual acuity is one of the most important prognostic factors used in clinical practice. In general, eyes with better preoperative visual acuity have more chance to attain better postoperative visual acuity, whereas eyes with worse preoperative visual acuity are likely to gain better visual improvements $[48,50-52]$. In an attempt to identify the factors influencing visual success in $\mathrm{MH}$ surgery, one study analysed 389 reported cases of $\mathrm{MH}$ surgery. In that study, the percentage of cases with a postoperative visual acuity of $6 / 12$ or better was significantly higher in the cases with a preoperative visual acuity greater than $6 / 60$, and the rate of 2 or more lines of improvement in visual acuity was significantly higher in the cases with a preoperative visual acuity of 6/60 or worse [45].

\section{Size of the $\mathrm{MH}$}

The preoperative size of the $\mathrm{MH}$ is known to be inversely correlated with visual outcomes: eyes with a larger diameter hole had worse visual outcomes [46]. In the investigation of 91 eyes enrolled in The Vitrectomy for Macular Hole Study Group, stepwise regression analysis revealed that the preoperative hole size was the only predictor of postoperative visual acuity [53]. Traditionally, $\mathrm{MH}$ size had been estimated based on biomicroscopic observation or photographic evaluation. As imaging technology developed and became applicable to fundus assessment, more attempts were made to measure $\mathrm{MH}$ size precisely [54, 55]. In 2002, Ip et al. [56] first used optical coherence tomography (OCT), the most common method used today, to quantify $\mathrm{MH}$ size. In a retrospective study of 40 eyes, a trend was found that greater visual acuity improvement was achieved in MHs smaller than $400 \mu \mathrm{m}$. Moreover, in a prospective study of 94 eyes, $\mathrm{MH}$ size measured by OCT was identified as being negatively correlated with postoperative visual acuity [57]. Gupta et al. [52] also reported that OCT-based preoperative $\mathrm{MH}$ size is a significant predictor of visual success. 
Table 1. Representative OCT parameters

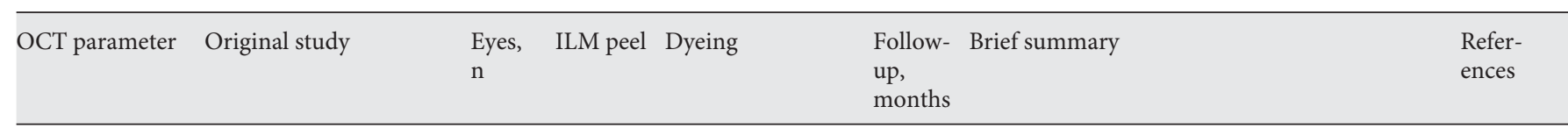

Cross-sectional image

\begin{tabular}{|c|c|c|c|c|c|c|c|}
\hline $\begin{array}{l}\text { Minimum hole } \\
\text { diameter }\end{array}$ & $\begin{array}{l}\text { Ip }[56], 2002 \\
\text { retrospective study }\end{array}$ & 40 & no & $\begin{array}{l}\text { autologous serum } \\
\text { ( } 20 \% \text { of eyes) }\end{array}$ & $\begin{array}{l}\text { not } \\
\text { known }\end{array}$ & $\begin{array}{l}\text { eyes with MHs smaller than } 400 \mu \mathrm{m} \text { tended to } \\
\text { have greater visual acuity improvement }\end{array}$ & $52,56-64$ \\
\hline $\begin{array}{l}\text { Basal hole } \\
\text { diameter }\end{array}$ & $\begin{array}{l}\text { Ullrich [57], } 2002 \\
\text { prospective study }\end{array}$ & 94 & yes & none & $\begin{array}{l}\text { not } \\
\text { known }\end{array}$ & $\begin{array}{l}\text { there was a negative correlation between basal } \\
\text { hole diameter and postoperative visual acuity }\end{array}$ & $\begin{array}{l}57-59,61 \\
63-65,67\end{array}$ \\
\hline Hole height & $\begin{array}{l}\text { Haritoglou [58], } 2007 \\
\text { retrospective study }\end{array}$ & 38 & yes & none & $60-75$ & $\begin{array}{l}\text { a negative correlation was seen between final } \\
\text { visual acuity and hole height }\end{array}$ & $\begin{array}{l}58,59,61 \\
63-65\end{array}$ \\
\hline $\begin{array}{l}\text { IS/OS junction } \\
\text { defect length }\end{array}$ & $\begin{array}{l}\text { Oh }[65], 2010 \\
\text { retrospective study }\end{array}$ & 23 & yes & $\begin{array}{l}\text { ICG ( } 13 \% \text { of eyes) } \\
\text { TA ( } 1 \% \text { of eyes) }\end{array}$ & $0.5-16$ & $\begin{array}{l}\text { neither best postoperative visual acuity nor } \\
\text { postoperative visual improvement was } \\
\text { correlated with preoperative IS/OS junction } \\
\text { defect length }\end{array}$ & $\begin{array}{l}64,65 \\
67-70\end{array}$ \\
\hline
\end{tabular}

\begin{tabular}{|c|c|c|c|c|c|c|c|}
\hline \multicolumn{8}{|c|}{ Indexes } \\
\hline $\mathrm{HFF}$ & $\begin{array}{l}\text { Ullrich [57], } 2002 \\
\text { prospective study }\end{array}$ & 94 & yes & none & $\begin{array}{l}\text { not } \\
\text { known }\end{array}$ & $\begin{array}{l}\text { the HFF was positively correlated with } \\
\text { postoperative visual acuity }\end{array}$ & $57,58,64$ \\
\hline$\overline{\mathrm{MHI}}$ & $\begin{array}{l}\text { Kusuhara [71], } 2004 \\
\text { prospective study }\end{array}$ & 35 & $\begin{array}{l}\text { yes }(83 \% \\
\text { of eyes })\end{array}$ & ICG (83\% of eyes) & $8-24$ & $\begin{array}{l}\text { the MHI had a positive correlation with } \\
\text { postoperative visual acuity }\end{array}$ & $\begin{array}{l}59,61,64 \\
65,71\end{array}$ \\
\hline THI & $\begin{array}{l}\text { Ruiz-Moreno [59], } 2008 \\
\text { retrospective study }\end{array}$ & 46 & yes & ICG & $12-60$ & $\begin{array}{l}\text { the THI significantly correlated with visual } \\
\text { acuity at postoperative } 3 \text { months }\end{array}$ & $59,61,64$ \\
\hline
\end{tabular}

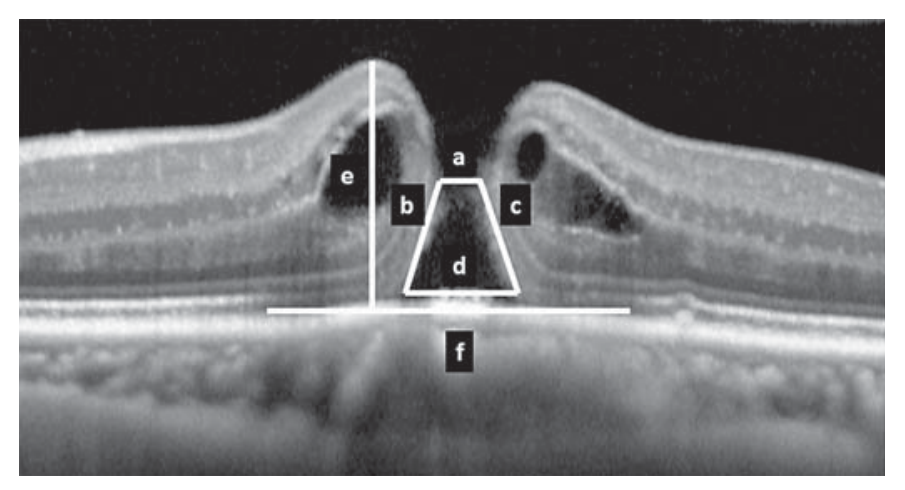

Fig. 1. MH parameters produced by OCT. a: minimum hole diameter; b: left arm length; c: right arm length; d: basal hole diameter; e: hole height; f: IS/OS defect length. HFF $=(b+c) / d ; M H I=e / d$; $\mathrm{THI}=\mathrm{e} / \mathrm{a}$.

\section{OCT Parameter and Index}

As OCT can produce a high-quality retinal image in a non-invasive manner, OCT imaging became essential in daily practice for the assessment of macular disorders, including $\mathrm{MH}$. Consequently, numerous attempts have been made to utilise the OCT parameters obtained from $\mathrm{MH}$ eyes to predict the visual outcomes (fig. 1). Table 1 shows the representative OCT parameters repeatedly discussed in previous papers in terms of their potential as preoperative predictors for postoperative visual outcomes. The mini- mum diameter of $\mathrm{MH}$, also known as the minimum linear dimension of $\mathrm{MH}$, is identical to the above-mentioned $\mathrm{MH}$ size, one of the most studied OCT parameters so far [52, 56-64]. Commonly, a smaller minimum diameter is associated with better postoperative visual acuity, irrespective of the presence/absence of a statistical significance. For example, in a retrospective study of 132 eyes, the predicted probability of visual success (better than 20/40) was $93 \%$ in patients less than 60 years of age with a minimum diameter $<350 \mu \mathrm{m}$ and a preoperative $\log$ MAR visual acuity $\geq 0.6$ [52]. The basal hole diameter is a linear dimension of $\mathrm{MH}$ at the level of the retinal pigment epithelium layer. The predictive trend of the basal hole diameter for visual outcomes is almost the same as the minimum diameter. The smaller the basal hole diameter becomes, the better the postoperative visual acuity is. In a retrospective study of 50 eyes, the odds of visual success (postoperative visual acuity $\geq 6 / 12$ ) decreased by $10 \%$ for every 26 - $\mu \mathrm{m}$ increase in the basal hole diameter [61]. However, there was a difference in the predictive performance between these two OCT parameters. In a retrospective case series of 38 eyes that were followed up for at least 5 years after surgery, the minimum diameter showed a significant correlation with the final visual acuity, whereas the basal hole diameter did not [58]. Although both the minimum diameter and basal hole diameter appear to be widely accepted as helpful for predicting visual outcomes following $\mathrm{MH}$ surgery, one report giving a contrary conclusion should be kept in mind. In a case 
series of 21 eyes that underwent $\mathrm{MH}$ surgery with $\mathrm{C}_{3} \mathrm{~F}_{8}$ gas tamponade and autologous platelet injection, no correlation was found between the minimum diameter and the visual acuity or visual improvement at 6 postoperative months [63]. The hole height is another preoperative OCT parameter, defined as the greatest distance between the retinal pigment epithelium layer and the vitreoretinal interface. Previous studies concluded that there is no significant relationship between the hole height and postoperative visual outcomes [58, 59, 61, 63-65], with the exception of one retrospective study showing a negative correlation between the hole height and visual acuity more than 5 years after $\mathrm{MH}$ surgery [58]. The photoreceptor inner segment/ outer segment (IS/OS) junction line can be better recognised as a hyperreflective band by spectral domain OCT imaging, and the relationship between the length of the IS/ OS junction defect and visual outcomes was recently investigated; although there is a debate as to whether this hyperreflective band corresponds to the IS/OS junction [66], the term 'IS/OS junction' is used in this review. The predictive performance of the IS/OS junction defect length for visual outcomes varies across the studies [64, 65, 67-70]. There are studies reporting that the preoperative IS/OS junction defect length is associated with the postoperative macular sensitivity and visual acuity $[67,68]$. However, in a retrospective case series of 51 eyes, no significant correlation was found between the preoperative IS/OS junction defect length and visual acuity up to 12 postoperative months [70]. We also investigated $50 \mathrm{MH}$ eyes and proved that the preoperative IS/OS defect length can predict visual success (visual acuity $\geq 20 / 28$ ) at 6 postoperative months. With a cut-off value of $1,500 \mu \mathrm{m}$, the specificity and sensitivity were 76 and 64\%, respectively [64]. The hole form factor (HFF) is the first calculated OCT index used as a prognostic factor [57]. The HFF is the quotient of the summation of the left and right arm lengths divided by the basal hole diameter. The HFF is reported to be positively correlated with the postoperative visual acuity, but the correlation is weaker than those for the minimum diameter and the basal hole diameter $[57,58]$. We proposed the $\mathrm{MH}$ index (MHI) as an intuitive predictor for visual outcome following $\mathrm{MH}$ surgery [71]. The MHI is defined as the ratio of the hole height to the basal hole diameter and is reported to be positively correlated to the postoperative visual acuity in several studies $[59,61,64,65]$. We also found that eyes with an MHI value $\geq 0.5$ had better visual acuity than those with an MHI value $<0.5$, which seems to be of great help in the clinical use of the MHI [71]. The tractional hole index (THI), defined as the ratio of the hole height to the minimum diameter, is another OCT index tested as a predictor for visual outcome. Ruiz-Moreno et al. [59] retrospectively examined 46 eyes and found that the THI significantly correlated with visual acuity at 3 postoperative months and that a THI value $>1.41$ is a predictive factor for a good visual prognosis (improvement of 2 or more Snellen lines). However, later studies failed to prove the significant predictive performance of the THI $[61,64]$. Other OCT parameters have also been tested as predictors of visual outcomes, including the external limiting membrane line defect length and the cone outer segment tips line defect length [59-61, 65, 68-70, 72].

As described above, many OCT-based predictors have been proposed so far, and it should be borne in mind that the results for these predictors vary across the studies. There are a multitude of factors that could cause this difference, such as OCT resolution. We recently reported that the reproducibility of the OCT measurement and possible off-centred OCT imaging can affect the predictive performance of each OCT parameter [64].

\section{Others}

A prospective study of 27 eyes revealed that pattern reversal visual evoked potential P100 latency and pattern electroretinogram N35 latency were significantly associated with visual outcomes [73]. In another prospective study involving 74 cases, both visual acuity and visual improvement at 6 postoperative months were greater when the visual acuity of the fellow eye was less than 20/200 [74]. Several retrospective case-control studies clarified that highly myopic eyes tended to have worse vision after $\mathrm{MH}$ surgery [75, 76]. Regarding the effect of the failure of prior MH surgery, Thompson and Sjaarda [77] retrospectively reviewed 16 patients with 2 failed $\mathrm{MH}$ surgeries and found that there was little or no benefit except for cases with at least 1 temporarily successful surgery. A RCT of 185 cases also reported that eyes in which the MH was closed after a second operation had slightly worse visual acuity [46]. A few research groups assessed the relationship between preoperative microperimetry values and visual outcomes, claiming that preoperative retinal sensitivity and fixation status are significantly correlated with the visual prognosis $[62,78,79]$.

\section{Future Direction}

Progress in surgical technology is likely to continue to improve the visual prognosis in eyes with $\mathrm{MHs}$ as vitreous surgery remains a mainstay of treatment. However, ocriplasmin, a truncated form of the human serine protease 
plasmin, recently became available for the treatment of $\mathrm{MHs}$, which means that $\mathrm{MH}$ patients now have a nonsurgical treatment option [80]. Accordingly, surgical indications for MHs will become an important topic from now on. Therefore, predicting visual outcomes precisely will become increasingly important. Future advancement of the evaluation methods could contribute greatly to this prediction.

\section{Disclosure Statement}

The authors have no financial support or conflicts of interest to declare.

\section{References}

1 Wang S, Xu L, Jonas JB: Prevalence of fullthickness macular holes in urban and rural adult Chinese: the Beijing Eye Study. Am J Ophthalmol 2006;141:589-591.

2 Jackson TL, Donachie PH, Sparrow JM, Johnston RL: United Kingdom National Ophthalmology Database study of vitreoretinal surgery: report 2, macular hole. Ophthalmology 2013;120:629-634.

-3 McCannel CA, Ensminger JL, Diehl NN, Hodge DN: Population-based incidence of macular holes. Ophthalmology 2009;116: 1366-1369.

$\checkmark 4$ Kelly NE, Wendel RT: Vitreous surgery for idiopathic macular holes. Results of a pilot study. Arch Ophthalmol 1991;109:654-659.

5 Park DW, Sipperley JO, Sneed SR, Dugel PU, Jacobsen J: Macular hole surgery with internal-limiting membrane peeling and intravitreous air. Ophthalmology 1999; 106:13921397, discussion 1397-1398.

6 Brooks HL Jr: Macular hole surgery with and without internal limiting membrane peeling. Ophthalmology 2000;107:1939-1948, discussion 1948-1949.

7 Sakamoto T, Ishibashi T: Visualizing vitreous in vitrectomy by triamcinolone. Graefes Arch Clin Exp Ophthalmol 2009;247:1153-1163.

$\checkmark 8$ Fabian ID, Moisseiev J: Sutureless vitrectomy: evolution and current practices. Br J Ophthalmol 2011;95:318-324.

-9 Tatham A, Banerjee S: Face-down posturing after macular hole surgery: a meta-analysis. Br J Ophthalmol 2010;94:626-631.

10 Chandra A, Charteris DG, Yorston D: Posturing after macular hole surgery: a review. Ophthalmologica 2011;226(suppl 1):3-9.

11 Bainbridge J, Herbert E, Gregor Z: Macular holes: vitreoretinal relationships and surgical approaches. Eye (Lond) 2008;22:1301-1309.

-12 Thompson JT, Glaser BM, Sjaarda RN, Murphy RP, Hanham A: Effects of intraocular bubble duration in the treatment of macular holes by vitrectomy and transforming growth factor-beta 2. Ophthalmology 1994;101: 1195-1200.

13 Thompson JT, Smiddy WE, Glaser BM, Sjaarda RN, Flynn HW Jr: Intraocular tamponade duration and success of macular hole surgery. Retina 1996;16:373-382.
14 Mulhern MG, Cullinane A, Cleary PE: Visual and anatomical success with short-term macular tamponade and autologous platelet concentrate. Graefes Arch Clin Exp Ophthalmol 2000;238:577-583.

15 Guillaubey A, Malvitte L, Lafontaine PO, Jay N, Hubert I, Bron A, Berrod JP, CreuzotGarcher C: Comparison of face-down and seated position after idiopathic macular hole surgery: a randomized clinical trial. Am J Ophthalmol 2008;146:128-134.

- 16 Tadayoni R, Vicaut E, Devin F, CreuzotGarcher C, Berrod JP, Le Mer Y, Korobelnik JF, Aout M, Massin P, Gaudric A: A randomized controlled trial of alleviated positioning after small macular hole surgery. Ophthalmology 2011;118:150-155.

17 Al-Abdulla NA, Thompson JT, Sjaarda RN: Results of macular hole surgery with and without epiretinal dissection or internal limiting membrane removal. Ophthalmology 2004;111:142-149.

18 Christensen UC, Kroyer K, Sander B, Larsen M, Henning V, Villumsen J, la Cour M: Value of internal limiting membrane peeling in surgery for idiopathic macular hole stage 2 and 3 : a randomised clinical trial. $\mathrm{Br} \mathrm{J}$ Ophthalmol 2009;93:1005-1015.

19 Lois N, Burr J, Norrie J, Vale L, Cook J, McDonald A, Boachie C, Ternent L, McPherson G: Internal limiting membrane peeling versus no peeling for idiopathic full-thickness macular hole: a pragmatic randomized controlled trial. Invest Ophthalmol Vis Sci 2011;52: 1586-1592.

20 Michalewska Z, Michalewski J, Adelman RA, Nawrocki J: Inverted internal limiting membrane flap technique for large macular holes. Ophthalmology 2010;117:2018-2025.

21 Stanescu-Segall D, Jackson TL: Vital staining with indocyanine green: a review of the clinical and experimental studies relating to safety. Eye (Lond) 2009;23:504-518.

22 Rodrigues EB, Meyer CH: Meta-analysis of chromovitrectomy with indocyanine green in macular hole surgery. Ophthalmologica 2008; 222:123-129.
23 Wu Y, Zhu W, Xu D, Li YH, Ba J, Zhang XL, Wang $\mathrm{F}, \mathrm{Yu}$ J: Indocyanine green-assisted internal limiting membrane peeling in macular hole surgery: a meta-analysis. PLoS One 2012; 7:e48405.

24 Teba FA, Mohr A, Eckardt C, Wong D, Kusaka S, Joondeph BC, Feron EJ, Stalmans P, Van Overdam K, Melles GR: Trypan blue staining in vitreoretinal surgery. Ophthalmology 2003;110:2409-2412.

25 Beutel J, Dahmen G, Ziegler A, Hoerauf H: Internal limiting membrane peeling with indocyanine green or trypan blue in macular hole surgery: a randomized trial. Arch Ophthalmol 2007;125:326-332.

26 Kimura H, Kuroda S, Nagata M: Triamcinolone acetonide-assisted peeling of the internal limiting membrane. Am J Ophthalmol 2004; 137:172-173.

27 Nomoto H, Shiraga F, Yamaji H, Fukuda K, Baba T, Takasu I, Ohtsuki H: Macular hole surgery with triamcinolone acetonide-assisted internal limiting membrane peeling: oneyear results. Retina 2008;28:427-432.

28 Veckeneer M, van Overdam K, Monzer J, Kobuch $\mathrm{K}$, van Marle W, Spekreijse H, van Meurs J: Ocular toxicity study of trypan blue injected into the vitreous cavity of rabbit eyes. Graefes Arch Clin Exp Ophthalmol 2001;239: 698-704.

29 Jin Y, Uchida S, Yanagi Y, Aihara M, Araie M: Neurotoxic effects of trypan blue on rat retinal ganglion cells. Exp Eye Res 2005;81:395400 .

30 Narayanan R, Mungcal JK, Kenney MC, Seigel GM, Kuppermann BD: Toxicity of triamcinolone acetonide on retinal neurosensory and pigment epithelial cells. Invest Ophthalmol Vis Sci 2006;47:722-728.

31 Ueno A, Hisatomi T, Enaida H, Kagimoto T, Mochizuki Y, Goto Y, Kubota T, Hata Y, Ishibashi T: Biocompatibility of brilliant blue $\mathrm{G}$ in a rat model of subretinal injection. Retina 2007;27:499-504.

32 Notomi S, Hisatomi T, Kanemaru T, Takeda A, Ikeda Y, Enaida H, Kroemer G, Ishibashi T: Critical involvement of extracellular ATP acting on P2RX7 purinergic receptors in photoreceptor cell death. Am J Pathol 2011;179: 2798-2809. 
- 33 Notomi S, Hisatomi T, Murakami Y, Terasaki H, Sonoda S, Asato R, Takeda A, Ikeda Y, Enaida H, Sakamoto T, Ishibashi T: Dynamic increase in extracellular ATP accelerates photoreceptor cell apoptosis via ligation of P2RX7 in subretinal hemorrhage. PLoS One 2013; 8:e53338.

-34 Shukla D, Kalliath J, Neelakantan N, Naresh $\mathrm{KB}$, Ramasamy K: A comparison of brilliant blue $\mathrm{G}$, trypan blue, and indocyanine green dyes to assist internal limiting membrane peeling during macular hole surgery. Retina 2011;31:2021-2025.

- 35 Baba T, Hagiwara A, Sato E, Arai M, Oshitari T, Yamamoto S: Comparison of vitrectomy with brilliant blue $\mathrm{G}$ or indocyanine green on retinal microstructure and function of eyes with macular hole. Ophthalmology 2012;119: 2609-2615.

-36 Fujii GY, De Juan E Jr, Humayun MS, Pieramici DJ, Chang TS, Awh C, Ng E, Barnes A, Wu SL, Sommerville DN: A new 25-gauge instrument system for transconjunctival sutureless vitrectomy surgery. Ophthalmology 2002;109:1807-1812, discussion 1813

- 37 Kusuhara S, Ooto S, Kimura D, Itoi K, Mukuno H, Miyamoto N, Akimoto M, Kuriyama S, Takagi H: Outcomes of 23- and 25-gauge transconjunctival sutureless vitrectomies for idiopathic macular holes. Br J Ophthalmol 2008;92:1261-1264.

- 38 Krishnan R, Tossounis C, Fung Yang Y: 20 -gauge and 23-gauge phacovitrectomy for idiopathic macular holes: comparison of complications and long-term outcomes. Eye (Lond) 2013;27:72-77.

-39 Goncu T, Gurelik G, Hasanreisoglu B: Comparison of efficacy and safety between transconjunctival 23-gauge and conventional 20 -gauge vitrectomy systems in macular surgery. Korean J Ophthalmol 2012;26:339-346.

-40 Oshima Y, Wakabayashi T, Sato T, Ohji M, Tano Y: A 27-gauge instrument system for transconjunctival sutureless microincision vitrectomy surgery. Ophthalmology 2010; 117:93-102.

-41 Kampougeris G, Cheema R, McPherson R, Gorman C: Safety of triamcinolone acetonide (TA)-assisted pars plana vitrectomy in macular hole surgery. Eye (Lond) 2007;21:591-594.

$\checkmark 42$ Cheng L, Azen SP, El-Bradey MH, Scholz BM, Chaidhawangul S, Toyoguchi M, Freeman WR: Duration of vitrectomy and postoperative cataract in the vitrectomy for macular hole study. Am J Ophthalmol 2001;132:881887.

43 Ohji M, Nao IN, Saito Y, Hayashi A, Tano Y: Prevention of visual field defect after macular hole surgery by passing air used for fluid-air exchange through water. Am J Ophthalmol 1999; 127:62-66.

- 44 Hirata A, Yonemura N, Hasumura T, Murata Y, Negi A: Effect of infusion air pressure on visual field defects after macular hole surgery. Am J Ophthalmol 2000;130:611-616.
45 Kang HK, Chang AA, Beaumont PE: The macular hole: report of an Australian surgical series and meta-analysis of the literature. Clin Experiment Ophthalmol 2000;28:298-308.

46 Ezra E, Gregor ZJ: Surgery for idiopathic fullthickness macular hole: two-year results of a randomized clinical trial comparing natural history, vitrectomy, and vitrectomy plus autologous serum: Moorfields Macular Hole Study Group report No 1. Arch Ophthalmol 2004;122:224-236.

47 Thompson JT, Sjaarda RN, Lansing MB: The results of vitreous surgery for chronic macular holes. Retina 1997;17:493-501.

48 Scott RA, Ezra E, West JF, Gregor ZJ: Visual and anatomical results of surgery for longstanding macular holes. Br J Ophthalmol 2000;84:150-153.

-49 Stec LA, Ross RD, Williams GA, Trese MT, Margherio RR, Cox MS Jr: Vitrectomy for chronic macular holes. Retina 2004;24:341347.

50 Jaycock PD, Bunce C, Xing W, Thomas D, Poon W, Gazzard G, Williamson TH, Laidlaw DA: Outcomes of macular hole surgery: implications for surgical management and clinical governance. Eye (Lond) 2005;19:879-884.

51 Thompson JT, Smiddy WE, Williams GA, Sjaarda RN, Flynn HW Jr, Margherio RR, Abrams GW: Comparison of recombinant transforming growth factor-beta-2 and placebo as an adjunctive agent for macular hole surgery. Ophthalmology 1998;105:700-706.

52 Gupta B, Laidlaw DA, Williamson TH, Shah SP, Wong R, Wren S: Predicting visual success in macular hole surgery. Br J Ophthalmol 2009;93:1488-1491.

53 Cheng L, Azen SP, El-Bradey MH, Toyoguchi M, Chaidhawangul S, Rivero ME, Scholz BM, Freeman WR: Effects of preoperative and postoperative epiretinal membranes on macular hole closure and visual restoration. Ophthalmology 2002;109:1514-1520.

54 Kobayashi H, Kobayashi K: Correlation of quantitative three-dimensional measurements of macular hole size with visual acuity after vitrectomy. Graefes Arch Clin Exp Ophthalmol 1999;237:283-288.

55 Byhr E, Lindblom B: Preoperative measurements of macular hole with scanning laser ophthalmoscopy. Correlation with functional outcome. Acta Ophthalmol Scand 1998;76: 579-583.

56 Ip MS, Baker BJ, Duker JS, Reichel E, Baumal CR, Gangnon R, Puliafito CA: Anatomical outcomes of surgery for idiopathic macular hole as determined by optical coherence tomography. Arch Ophthalmol 2002;120:2935.

57 Ullrich S, Haritoglou C, Gass C, Schaumberger M, Ulbig MW, Kampik A: Macular hole size as a prognostic factor in macular hole surgery. Br J Ophthalmol 2002;86:390-393.
58 Haritoglou C, Neubauer AS, Reiniger IW, Priglinger SG, Gass CA, Kampik A: Longterm functional outcome of macular hole surgery correlated to optical coherence tomography measurements. Clin Experiment Ophthalmol 2007;35:208-213.

59 Ruiz-Moreno JM, Staicu C, Pinero DP, Montero J, Lugo F, Amat P: Optical coherence tomography predictive factors for macular hole surgery outcome. Br J Ophthalmol 2008;92: 640-644.

60 Kim NM, Park HJ, Koo GH, Lee JE, Oum BS: Photoreceptor layer assessed in tissue layer image using spectral-domain optical coherence tomography after surgical closure of macular hole. Retina 2011;31:1483-1492.

61 Wakely L, Rahman R, Stephenson J: A comparison of several methods of macular hole measurement using optical coherence tomography, and their value in predicting anatomi$\mathrm{cal}$ and visual outcomes. Br J Ophthalmol 2012;96:1003-1007.

62 Sun Z, Gan D, Jiang C, Wang M, Sprecher A, Jiang AC, Xu G: Effect of preoperative retinal sensitivity and fixation on long-term prognosis for idiopathic macular holes. Graefes Arch Clin Exp Ophthalmol 2012;250:1587-1596.

63 Konstantinidis A, Hero M, Nanos P, Panos GD: Efficacy of autologous platelets in macular hole surgery. Clin Ophthalmol 2013;7: 745-750.

64 Matsumiya W, Kusuhara S, Shimoyama T, Honda S, Tsukahara Y, Negi A: Predictive value of preoperative optical coherence tomography for visual outcome following macular hole surgery: effects of imaging alignment. Jpn J Ophthalmol 2013;57:308-315.

65 Oh J, Smiddy WE, Flynn HW Jr, Gregori G, Lujan B: Photoreceptor inner/outer segment defect imaging by spectral domain OCT and visual prognosis after macular hole surgery. Invest Ophthalmol Vis Sci 2010;51:16511658.

66 Spaide RF, Curcio CA: Anatomical correlates to the bands seen in the outer retina by optical coherence tomography: literature review and model. Retina 2011;31:1609-1619.

67 Grigoropoulos VG, Theodossiadis GP, Theodossiadis PG: Association of the preoperative photoreceptor layer defect as assessed by optical coherence tomography with the functional outcome after macular hole closure: a long follow-up study. Ophthalmologica 2011;225: 47-54.

68 Ooka E, Mitamura Y, Baba T, Kitahashi M, Oshitari T, Yamamoto S: Foveal microstructure on spectral-domain optical coherence tomographic images and visual function after macular hole surgery. Am J Ophthalmol 2011; 152:283-290.e1.

69 Chen WC, Wang Y, Li XX: Morphologic and functional evaluation before and after successful macular hole surgery using spectraldomain optical coherence tomography combined with microperimetry. Retina 2012;32: 1733-1742.
Predicting Visual Outcome after $\mathrm{MH}$ Surgery
Ophthalmologica 2014;231:125-132 
70 Itoh Y, Inoue M, Rii T, Hiraoka T, Hirakata A: Correlation between length of foveal cone outer segment tips line defect and visual acuity after macular hole closure. Ophthalmology 2012;119:1438-1446.

71 Kusuhara S, Teraoka Escano MF, Fujii S, Nakanishi Y, Tamura Y, Nagai A, Yamamoto H, Tsukahara Y, Negi A: Prediction of postoperative visual outcome based on hole configuration by optical coherence tomography in eyes with idiopathic macular holes. Am J Ophthalmol 2004;138:709-716.

72 Chung SE, Lim DH, Kang SW, Yoon YH, Chae JB, Roh IH: Central photoreceptor viability and prediction of visual outcome in patients with idiopathic macular holes. Korean J Ophthalmol 2010;24:213-218.
73 Tilanus MA, Cuypers MH, Bemelmans NA, Pinckers AJ, Deutman AF: Predictive value of pattern VEP, pattern ERG and hole size in macular hole surgery. Graefes Arch Clin Exp Ophthalmol 1999;237:629-635.

74 Kadonosono K, Yabuki K, Nishide T, Uchio E, Marron JA: Measured visual acuity of fellow eyes as a prognostic factor in macular hole surgery. Am J Ophthalmol 2003;135:493498.

75 Sulkes DJ, Smiddy WE, Flynn HW, Feuer W: Outcomes of macular hole surgery in severely myopic eyes: a case-control study. Am J Ophthalmol 2000;130:335-339.

76 Wu TT, Kung YH: Comparison of anatomical and visual outcomes of macular hole surgery in patients with high myopia vs. non-high myopia: a case-control study using optical coherence tomography. Graefes Arch Clin Exp Ophthalmol 2012;250:327-331.
77 Thompson JT, Sjaarda RN: Surgical treatment of macular holes with multiple recurrences. Ophthalmology 2000;107:1073-1077.

78 Amari F, Ohta K, Kojima H, Yoshimura N: Predicting visual outcome after macular hole surgery using scanning laser ophthalmoscope microperimetry. Br J Ophthalmol 2001;85: 96-98.

79 Hikichi T, Kitaya N, Takahashi J, Ishiko S, Mori F, Yoshida A: Association of preoperative photoreceptor displacement and improved central scotoma after idiopathic macular hole surgery. Ophthalmology 2002;109: 2160-2164.

80 Stalmans P, Benz MS, Gandorfer A, Kampik A, Girach A, Pakola S, Haller JA: Enzymatic vitreolysis with ocriplasmin for vitreomacular traction and macular holes. N Engl J Med 2012;367:606-615. 